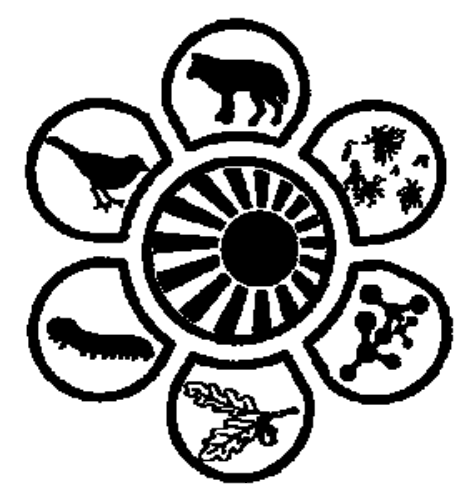

Вісник Дніпропетровського університету. Біологія, екологія.

Vìsnik Dnìpropetrovs'kogo unìversitetu. Seriâ Bìologiâ, ekologiâ

Visnyk of Dnipropetrovsk University. Biology, ecology.

Vìsn. Dnìpropetr. Unìv. Ser. Bìol. Ekol. 2015. 23(2), 105-111.

doi: $10.15421 / 011515$

ISSN 2310-0842 print

ISSN 2312-301X online

www.ecology.dp.ua

УДК 581.524.1

\title{
Віталітетна структура та їі динаміка у Quercus robur на початкових етапах онтогенезу
}

\author{
В.М. Дегтярьов, В.Г. Скляр
}

Сумський національний аграрний університет, Суми, Україна

Наведено результати оцінювання віталітетної структури онтогенетичних субценопопуляцій ювенільних (j) та імматурних (im1 та im2) рослин Quercus robur L. у семи угрупованнях лісової рослинності Кролевецько-Глухівського геоботанічного району. Встановлено, що онтогенетичні субценопопуляції молодого покоління Q. robur, які формуються під наметом широколистяних лісів регіону, вирізняються високим рівнем різноманіття віталітетної структури та належністю до трьох якісних типів: процвітаючих, врівноважених і депресивних. Перехід до кожного наступного етапу розвитку (від ј до im1, а також від im1 до im2) супроводжується проявом у молодого покоління $Q$. robur віталітетної пластичності (тобто зміни величин індексу Q) та, відповідно, віталітетної мінливості (зміни частки особин різних класів віталітету). Кількісні та якісні аспекти реалізації віталітетної пластичності оцінено з опорою на оригінальний показник - індекс віталітетної динаміки (IVD). У Q. robur на початкових фазах онтогенезу негативні зміни віталітетної структури відбуваються частіше, ніж позитивні. Вони здебільшого супроводжуються зниженням «якісного» статусу когорт. Установлено факти щодо віталітетної структури онтогенетичних субценопопуляцій ювенільних та імматурних (im1 та im2) рослин, які об’єктивно свідчать про ускладненість формування у фітоценозах за участі Q. robur безперервного потоку поколінь цього виду, та, відповідно, забезпечення стійкого та довготривалого існування його ценопопуляцій.

Ключові слова: віталітет; онтогенетичний розвиток; індекс якості популяції; індекс віталітетної динаміки; КролевецькоГлухівський геоботанічний район

\section{Quercus robur vitality structure and its dynamics at the initial stages of ontogeny}

\author{
V.M. Dehtiarov, V.G. Skliar \\ Sumy National Agrarian University, Sumy, Ukraine
}

We present the results of evaluation of vitality structure of ontogenetic subcenopopulations of juvenile and immature (im1 and im2) plants Quercus robur L. in seven aggregations of forest vegetation of Krolevets-Hlukhiv Geobotanical Region. It is found that ontogenetic subcenopopulations of $Q$. robur young generation, formed under canopy of deciduous forests of the region under study, are noted for high level of vitality structure diversity and for having three qualitative types: blooming, balanced and depressive ones. It is observed that dynamics of $\mathrm{Q}$ quality index values in ontogenetic subcenopopulations $Q$. robur in the aggregations under study fits three variants of changes. In the first one we can see stable decrease of Q quality index values in the line $\mathrm{j} \rightarrow \mathrm{im} 1 \rightarrow \mathrm{im} 2$. Three of seven aggregations under study have dynamics of Q index values fitting the variant where increase of values takes place in the phase $\mathrm{j} \rightarrow \mathrm{im} 1$, and their decrease occurs in the phase im $1 \rightarrow \mathrm{im} 2$. Q index values also decrease in the phase $\mathrm{j} \rightarrow \mathrm{im} 1$ and their increase in the phase im $1 \rightarrow \mathrm{im} 2$ is established in three more phytocenoces. It is proved that change to every next phase of development (from $\mathrm{j}$ to im1, and also from im1 to im2) is accompanied by the appearance of vitality plasticity in $Q$. robur young generation (i.e. Q quality index value changes) and vitality variability (changes of share of individuals of various vitality classes), respectively. Quantitative as well as qualitative aspects of vitality plasticity realization are evaluated based on the original factor - index of vitality dynamics - IVD. It is found that at the initial stages of ontogenetic development negative changes of vitality structure in $Q$. robur happen more often then positive ones. Decrease in the individuals' vitality and worsening of vitality structure are mainly accompanied by the reduction of cohort quality status. Ascertained facts as for vitality structure of ontogenetic subcenopopulations of juvenile and immature (im1 and im2) plants fairly prove the complicated nature of formation of continuous flow of $Q$. robur generations in phytocenoses with the appearance of this species and assurance of stable and lasting existence of its cenopopulations, respectively. From the peculiarities of vitality structure and its dynamics, we assume that considerable transformation

Сумський національний аграрний університет, вул. Герасима Кондратьєва, 160, Суми, 40021, Україна Sumy National Agrarian University, Gerasim Kondratyev Str., 160, Sumy, 40021, Ukraine

Tel.: +38-097-309-71-09.E-mail:skvig@mail.ru 
of species composition of forest stands as a result of Q. robur reduction in their composition may happen in forests Tilieto (cordatae)Acereto (platanoiditis)-Quercetum (roboris) stellariosum (holosteae) and Quercetum (roboris) acereto (tatarici)-urticosum (dioicae) in the studied region in future.

Keywords: vitality; ontogenetic development; index of population quality; index of vitality dynamics; Krolovets-Hlukhiv Geobotanical Region

\section{Вступ}

У рослинному покриві Землі лісам належить провідна роль за зайнятою площею та значенням (Cramer, 1999; Filipovitch, 2001; Sheljag-Sosonko, 2001, 2003; Sytnyk, 2003; Stojko, 2006; Bobyliov et al., 2014). Властивості лісових фітоценозів, виконання ними екологостабілізувальних, созологічних і господарських функцій суттєво залежать від видового складу лісотвірних видів (Popaduk, 1995), до яких належить і дуб звичайний (Quercus robur L.).

Q. robur - типово європейський вид, поширений від Піренейського півострова до Уралу (Bukshtynov, 1959; Rysin, 1990; Brewer, 2002; Petit, 2002). Ліси, у яких цей вид домінує, зазвичай вирізняються високим біорізноманіттям, наявністю раритетних видів, що мають офіційний статус тих чи інших рангів охорони (міжнародного, державного чи регіонального), а також потужною середовищетвірною дією (Joshi et al., 1997).

Iз середини XIX сторіччя, зокрема, внаслідок зростання антропогенного тиску на навколишнє середовище, розвитку глобальної екологічної кризи, збільшення обсягів заготівлі деревини $Q$. robur як господарсько цінної породи, у лісових угрупованнях за участі цього виду наочними стали негативні тенденції в динаміці стану, поширенні, стійкості (Thomas and Boza, 1984; Oleksyn and Przyby1, 1987; Kaus et al., 1995; Burslern end Whitmore, 1999; Thomas, 2008). Невипадково у 2007 році Q. robur включено до «Червоного списку МСОП» (IUCN Red List) як вид, що нині є досить розповсюдженим, однак унаслідок зменшення чисельності потребує уважного ставлення, вивчення стану популяцій із метою їх збереження та недопущення втрати.

Одним із чинників, визначальних щодо забезпечення стійкого функціонування популяцій $Q$. robur та угруповань за його участі, є процес появи, росту та розвитку під наметом материнських деревостанів молодих рослин цього виду (Niinemets, 1998). У свою чергу, у будь-якій популяції успішність процесу колообігу поколінь зазвичай залежить від кількості та, особливо, - життєвості особин нової генерації (Smirnova et al., 1999; Schütz, 2002). При цьому у лісотвірних видів часто критичним етапом щодо формування безперервних потоків поколінь $є$ проходження особинами початкових фаз онтогенезу, зокрема, ювенільної та імматурної. Рослини цих станів вельми чутливі до різних зовнішніх впливів, i, відповідно, рівень їх смертності, у тому числі через низьку життєвість, може істотно відбитися і на здатності популяцій до тривалого існування на зайнятій території (Chistjakova, 1987).

Для оцінки життєвості рослин деревних видів застосовують різні підходи, які досить часто базуються на характеристиці стану особин за 1-3 випадково обраними кількісними чи якісними ознаками. Як доводить досвід популяційних досліджень, у зазначеному аспекті доцільне інформативне застосування віталітетного аналізу (Suhoj,
1986; Bashtovoj, 1992; Panchenko 2005, 2007, 2009; Kovalenko, 2006; Kashin, 2009; Skljar, 2015). Його теоретичні засади та алгоритм сформульовані Ю.А. Злобіним (Zlobin, 1989, 2009). Класичний віталітетний аналіз має на меті оцінку життєвості особин за декількома морфологічними показниками, попередньо встановленими завдяки застосуванню комплексу методів математичної статистики (точкового, кореляційного та факторного рішень), із подальшим з'ясуванням співвідношення в популяції кількості особин різного віталітету. Незважаючи на наявні наукові напрацювання, в аспекті віталітетного аналізу ще мало розроблене та апробоване питання щодо зміни рівня життєвості рослин в онтогенезі (Skljar, 2013).

3 урахуванням екологічної, созологічної та господарської цінності популяцій $Q$. robur, важливості забезпечення їх стійкого функціонування, а також ступеня вивченості питання, оцінка у цього виду віталітету рослин на ранніх етапах онтогенезу та визначення тенденцій у динаміці зазначеної характеристики у процесі їх росту та розвитку, є актуальною науковою проблемою. Її розроблення особливо значуще для регіонів, де ліси із $Q$. robur відіграють важливу роль у формуванні екологічного каркаса та функціонуванні лісогосподарського комплексу. В Україні до таких територій, зокрема, належить Кролевецько-Глухівській геоботанічний район (Andrijenko, 1977). Він розташований у межах північного сходу України та оточений такими геоботанічними районами: на північному заході - Новгородсіверсько-Понорницьким, на півночі - Шостківським, а на півдні - Конотопським, зі сходу майже по державному кордону з Російською Федерацією - Рильським, на заході - Олишівсько-Коропським. Лісові фітоценози, в основному представлені широколистяними угрупованнями, вкривають близько 11\% території регіону. Однак площа лісів із домінуванням Q. robur кожного року стає меншою. Їх витісняють угруповання, в яких у деревостані переважають береза повисла (Betula pendula Roth.), клен гостролистий (Acer platanoides L.), ясен звичайний (Fraxinus excelsior L.) (Andrijenko, 2001).

Мета цієї статті - встановити у молодого покоління Q. robur ювенільного та імматурного станів, наявного під наметом лісових фітоценозів КролевецькоГлухівського геоботанічного району, віталітетну структуру та характер її динаміки.

\section{Матеріал і методи досліджень}

В основу статті покладено результати досліджень, які здійснено в межах Кролевецько-Глухівського геоботанічного району з 2012 року. Фактичний матеріал отримано за результатами опису майже 120 облікових площ та обстеження семи угруповань лісової рослинності. Вивченням охоплено такі фітоценози: 1. Quercetum (roboris) convallariosum (majalis), 2. Quercetum (roboris)-Acereto (platanoiditis) aegopodiosum (podagrariae), 3. Tilieto (cordatae)Quercetum (roboris) coryloso (avellanae)-aegopodiosum (po- 
dagrariae), 4. Quercetum (roboris) coryloso (avellanae) dryopteridosum (filix-maris), 5. Quercetum (roboris) coryloso (avellanae)-convallariosum (majalis), 6. Tilieto (cordatae)Acereto (platanoiditis)-Quercetum (roboris) stellariosum (holosteae), 7. Quercetum (roboris) acereto (tatarici)urticosum (dioicae).

У дослідженні онтогенетичної структури ценопопуляцій $Q$. robur використано загальноприйняті методичні підходи, відображені в наукових розробках О.В. Смирнової, А.А. Чистякової, Л.Б. Заугольнової (Smirnova et al., 1999) та інших. В особин $Q$. robur виділено такі онтогенетичні стани: проростки (p) - рослини без галуження, що сформувались із насіння в рік його проростання; ювенільний (j) - невеличкі за розміром рослини без галуження з листками ювенільного типу; імматурний (im) особини, у яких наявні бічні пагони другого-п'ятого порядків, а діаметр стовбура не більше ніж удвічі перевищує діаметр бічних гілок; віргінільний (v) - особини, які мають характерну для дорослих рослин морфологічну структуру, однак ще не набули здатності до формування генеративних органів; генеративний (g) дерева, які вступили у фазу генеративного розмноження та підтримують його протягом декількох років чи десятиліть; сенільний (s) - старі дерева, які втратили або втрачають здатність до генеративного розмноження та мають вторинну крону з листям чи хвоєю ювенільного типу. Серед імматурних рослин, додатково, виділялися особини станів im1 та im2. Особини im1 в основному розташовані у трав'янисто-чагарничковому ярусі, а im2 виходять із нього до ярусу підліску.

Кожну із трьох груп рослин (ювенільного, імматурного (im1 та im2) станів) розглядали як окрему онтогенетичну субценопопуляцію. У досліджуваних угрупованнях за випадковою системою відбирали 20-40 рослин $Q$. robur кожної із зазначених субценопопуляцій. У цих рослин, відповідно до загальноприйнятих підходів (Hunt, 1978; Zlobin, 1989), оцінено їх розмір. Морфометричний аналіз включав оцінку алометричних статичних і динамічних показників (фітомаси надземної частини, загальної фітомаси листків та одного листка, висоти особин, загальної площі листкової поверхні та площі одного листка, кількості листків, кількості бічних пагонів, діаметра стебла, фотосинтетичного зусилля, відносного приросту та ін.).

Відповідно до вимог віталітетного аналізу, з опорою на три ключові морфологічні параметри у складі досліджуваних онтогенетичних субценопопуляцій виділено рослини трьох класів віталітету (високого клас «а», проміжного - клас «b» і низького - клас «с») та встановлено частку рослин кожного із цих класів. 3 огляду на отримані результати розраховано індекс якості $(\mathrm{Q}=1 / 2(\mathrm{a}+\mathrm{b}))$ та встановлено приналежність онтогенетичних субценопопуляцій до одного із трьох якісних типів: депресивного - Q змінюється від 0 до 0,166 , врівноваженого - Q від 0,167 до 0,332 або процвітаючого - Q від 0,333 до 0,500.

Динаміку віталітетних показників оцінювали виходячи 3 теоретичного узагальнення щодо можливості вираженості у цих характеристик просторово-часової пластичності та просторово-часової мінливості. Перша 3 них проявляється зміною індексу якості певних популяцій (субценопопуляцій, когорт) за різними місцезростаннями або у часі. Просторово-часова мінливість реалізується через зміну співвідношення у складі тих чи інших сукупностей рослин особин різних класів віталітету (a, b або c) (Skljar, 2013).

Кількісні та якісні аспекти реалізації віталітетної пластичності оцінювали 3 урахуванням оригінального показника - індексу віталітетної динаміки (IVD - index of vitality dynamics), що розраховували за формулою:

$$
\mathrm{IVD}=(\mathrm{Qn}-\mathrm{Qp}) / 0,166
$$

де Qn - значення індексу якості субценопопуляції на наступному етапі розвитку, Qp - значення індексу якості субценопопуляції на попередньому етапі розвитку, 0,166 величина індексу якості, на рівні якої відбувається перехід популяцій з одного якісного типу в наступний. За IVD = 0 у субценопопуляцій зміни індексу якості Q за етапами розвитку відсутні. Якщо IVD (за модулем) менше 1 - зміни незначні. Якщо IVD (за модулем) перебуває в межах від 1 до 2 - зміни суттєві. Якщо IVD (за модулем) більший 2 - зміни значні. За від'ємних значень IVD відбувається погіршення стану субценопопуляції, за позитивних - поліпшення.

У процесі аналізу динаміки віталітетних показників за етапами розвитку оцінювали і те, супроводжуються ці зміни «виходом» онтогенетичних субценопопуляцій із діапазону показників певного якісного типу (наприклад, ï переходом із категорії врівноважених у категорію депресивних) чи ні.

\section{Результати та їх обговорення}

В особин $Q$. robur до морфопараметрів, які визначають рівень їх віталітету, належать висота, фітомаса надземної частини та загальна площа листкової поверхні. Віталітетна структура онтогенетичних субценопопуляцій ювенільних та імматурних (im1 та im2) рослин була 3'ясована грунтуючись саме на цих розмірних характеристиках. Досліджувані фітоценози характеризуються суттевими відмінностями віталітетної структури молодого покоління Q. robur (табл. 1). Онтогенетичні субценопопуляції ювенільних рослин або процвітаючі, або врівноважені. До першого якісного типу належать субценопопуляції з угруповань Quercetum (roboris) convallariosum (majalis) $(\mathrm{Q}=0,500)$, Tilieto (cordatae)-Quercetum (roboris) coryloso (avellanae)-aegopodiosum (podagrariae) ( $\mathrm{Q}=$ 0,361), Quercetum (roboris)-Acereto (platanoiditis) aegopodiosum (podagrariae) $(\mathrm{Q}=0,357)$. До другого - iз Quercetum (roboris) coryloso (avellanae)-convallariosum (majalis) $(\mathrm{Q}=$ 0,281), Quercetum (roboris) coryloso (avellanae)dryopteridosum (filix-maris) $(\mathrm{Q}=0,250)$, Tilieto (cordatae)Acereto (platanoiditis)-Quercetum (roboris) stellariosum (holosteae) ( $\mathrm{Q}=0,250)$, Quercetum (roboris) acereto (tatarici)-urticosum (dioicae) $(\mathrm{Q}=0,220)$.

Онтогенетичні субценопопуляції імматурних рослин першої групи (im1) за віталітетною структурою репрезентують всі три якісні типи. Процвітають субценопопуляції з угруповань Quercetum (roboris)-Acereto (platanoiditis) aegopodiosum (podagrariae) $(\mathrm{Q}=0,367)$ та Tilieto (cordatae)Quercetum (roboris) coryloso (avellanae)-aegopodiosum (podagrariae) $(\mathrm{Q}=0,363)$, врівноважені - iз фітоценозів Quercetum (roboris) coryloso (avellanae)-dryopteridosum (filix-maris) $(\mathrm{Q}=0,306)$, Quercetum (roboris) convallariosum 
(majalis) $(\mathrm{Q}=0,267)$, Tilieto (cordatae)-Acereto (platanoiditis)-Quercetum (roboris) stellariosum (holosteae) $(\mathrm{Q}=0,211)$, Quercetum (roboris) coryloso (avellanae)-convallariosum (majalis) $(\mathrm{Q}=0,193)$. Одна субценопопуляція (з угруповання Quercetum (roboris) acereto (tatarici)-urticosum (dioiсае) є депресивною $(\mathrm{Q}=0,105)$.

Онтогенетичні субценопопуляції імматурних рослин другої групи (im2) також належать до трьох якісних типів. Процвітає субценопопуляція з угруповання Quercetum (roboris) convallariosum (majalis) $(\mathrm{Q}=0,400)$, врівноважена 3 угруповань Quercetum (roboris)-Acereto (platanoiditis) aegopodiosum (podagrariae) $(\mathrm{Q}=0,311)$, Quercetum (roboris) coryloso (avellanae)-convallariosum (majalis) $(\mathrm{Q}=0,304)$, Tilieto (cordatae)-Quercetum (roboris) coryloso (avellanae)aegopodiosum (podagrariae) $(\mathrm{Q}=0,250)$, Quercetum (roboris) coryloso (avellanae)-dryopteridosum (filix-maris) ( $\mathrm{Q}=$ 0,227). Дві субценопопуляції (з угруповань Tilieto (cordatae)-Acereto (platanoiditis)-Quercetum (roboris) stellariosum (holosteae) та Quercetum (roboris) acereto (tatarici)urticosum (dioicae)) є депресивними та, відповідно, мають значення індексу якості Q на рівні 0,139 і 0,136.

Віталітетна структура молодого покоління $Q$. robur

Таблиияя 1 у різних лісових фітоценозах Кролевецько-Глухівського геоботанічного району

\begin{tabular}{|c|c|c|c|c|c|c|c|c|c|}
\hline \multirow{3}{*}{ Угруповання } & \multicolumn{9}{|c|}{ Онтогенетичні субценопопуляції різних етапів розвитку } \\
\hline & \multicolumn{3}{|c|}{$\mathrm{j}$} & \multicolumn{3}{|c|}{$\operatorname{im}_{1}$} & \multicolumn{3}{|c|}{$\mathrm{im}_{2}$} \\
\hline & клас а & клас b & клас с & клас a & клас b & клас с & клас а & клас b & клас с \\
\hline Quercetum (roboris) convallariosum (majalis) & 0,000 & 1,000 & 0,000 & 0,333 & 0,200 & 0,467 & 0,200 & 0,600 & 0,200 \\
\hline $\begin{array}{l}\text { Quercetum (roboris)-Acereto (platanoiditis) aegopodiosum } \\
\text { (podagrariae) }\end{array}$ & 0,429 & 0,285 & 0,286 & 0,667 & 0,067 & 0,266 & 0,375 & 0,250 & 0,375 \\
\hline $\begin{array}{l}\text { Tilieto (cordatae)-Quercetum (roboris) coryloso (avellanae)- } \\
\text { aegopodiosum (podagrariae) }\end{array}$ & 0,555 & 0,167 & 0,278 & 0,546 & 0,182 & 0,272 & 0,375 & 0,125 & 0,500 \\
\hline $\begin{array}{l}\text { Quercetum (roboris) coryloso (avellanae)-dryopteridosum } \\
\text { (filix-maris) }\end{array}$ & 0,500 & 0,000 & 0,500 & 0,611 & 0,000 & 0,389 & 0,455 & 0,000 & 0,545 \\
\hline Quercetum (roboris) coryloso (avellanae)-convallariosum (majalis) & 0,500 & 0,063 & 0,437 & 0,385 & 0,00 & 0,615 & 0,522 & 0,087 & 0,391 \\
\hline $\begin{array}{l}\text { Tilieto (cordatae)-Acereto (platanoiditis)-Quercetum (roboris) } \\
\text { stellariosum (holosteae) }\end{array}$ & 0,500 & 0,000 & 0,500 & 0,421 & 0,000 & 0,579 & 0,277 & 0,000 & 0,723 \\
\hline Quercetum (roboris) acereto (tatarici)-urticosum (dioicae) & 0,440 & 0,000 & 0,560 & 0,211 & 0,000 & 0,789 & 0,273 & 0,000 & 0,727 \\
\hline
\end{tabular}

Процвітаючі онтогенетичні субценопопуляції вирізняються переважанням у їх складі сумарної частки рослин класів а та b віталітету, частка яких у деяких угрупованнях (наприклад, Quercetum (roboris) convallariosum (majalis)) сягає максимально можливого показника - 1,0 або є близькою до нього. У депресивних субценопопуляціях найбільшою є частка рослин класу с віталітету, яка у низці фітоценозів (Tilieto (cordatae)-Acereto (platanoiditis)Quercetum (roboris) stellariosum (holosteae), Quercetum (roboris) acereto (tatarici)-urticosum (dioicae)) становить близько 72-79\%.

Загалом у Кролевецько-Глухівському геоботанічному районі при переході від наймолодших (j) до старших онтогенетичних субценопопуляцій (im2) має місце досить чітко виражена тенденція до збільшення представленості субценопопуляцій категорії «депресивні». Крім того, відбувається зменшення індексу якості Q: у ювенільних онтогенетичних субценопопуляцій значення цього показника варіюють у межах 0,22-0,50, а в імматурних другої групи -0,136-0,400.

Зміни індексу якості Q в онтогенетичних субценопопуляцій $Q$. robur у кожному з досліджуваних угруповань проілюстровано на рисунку. Загалом динаміка значень цього показника відповідає трьом варіантам трендів.

Периий варіант динаміки показників. В ряду $\mathrm{j} \rightarrow \mathrm{im} 1$ $\rightarrow$ im2 відбувається стійке зниження індексу якості Q. Це характерно для угруповання Tilieto (cordatae)-Acereto (platanoiditis)-Quercetum (roboris) stellariosum (holosteae). У цьому угрупованні зменшення показників на етапі $\mathrm{j} \rightarrow$ iml незначне $(\mathrm{IVD}=-0,238)$ і не супроводжується «виходом» субценопопуляції з діапазону показників якісного типу врівноважених. На етапі im1 $\rightarrow$ im2 зменшення індексу якості також незначне (IVD $=-0,837)$, однак воно спричинює перехід досліджуваних сукупностей рослин із категорії врівноважених до категорії депресивних (табл. 2).

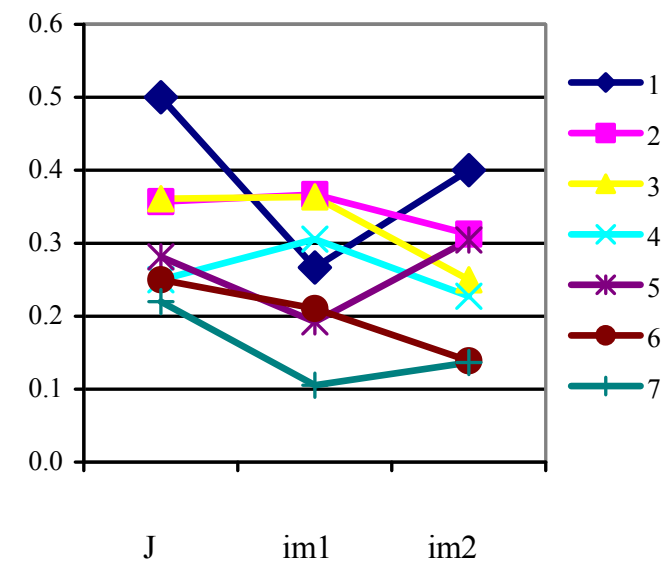

Рис. Зміна індексу якості в онтогенетичних субценопопуляцій Quercus robur за етапами розвитку: нумерація фітоценозів відповідає наведеній у таблиці 2

Другий варіант динаміки показників. На етапі $\mathrm{j} \rightarrow$ im1 має місце збільшення значень індексу Q, а на етапі $\mathrm{im} 1 \rightarrow \mathrm{im} 2$ - ї зменшення. Ця модель реалізується в угрупованнях Quercetum (roboris)-Acereto (platanoiditis) aegopodiosum (podagrariae), Tilieto (cordatae)-Quercetum (roboris) coryloso (avellanae)-aegopodiosum (podagrariae), Quercetum (roboris) coryloso (avellanae)-dryopteridosum (filix-maris). Зростання значень Q на етапі $\mathrm{j} \rightarrow \mathrm{im1}$ загалом незначне (IVD $=0,015-0,335)$. В угрупованнях 
Quercetum (roboris)-Acereto (platanoiditis) aegopodiosum (podagrariae), Tilieto (cordatae)-Quercetum (roboris) coryloso (avellanae)-aegopodiosum (podagrariae) воно відбувається у межах одного якісного типу «процвітаючих», тоді як в Quercetum (roboris) coryloso (avellanae)-dryopteridosum (filix-maris) сприяє переходу субценопуляцій із категорії врівноважених до процвітаючих. На етапі im1 $\rightarrow \mathrm{m} 2$ в усіх трьох фітоценозах зменшення індексу якості Q при величинах IVD від $-0,684$ до $-0,327$ супроводжується переходом онтогенетичних субценопопуляцій із процвітаючих до врівноважених.

Третій варіант динаміки показників. На етапі $\mathrm{j} \rightarrow$ iml має місце зменшення індексу Q, а на етапі $\mathrm{im} 1 \rightarrow$ im2 - його збільшення. Ця модель реалізується в угрупованнях Quercetum (roboris) convallariosum (majalis), Quercetum (roboris) coryloso (avellanae)-convallariosum (majalis), Quercetum (roboris) acereto (tatarici)-urticosum (dioicae). У першому з них на етапі $\mathrm{j} \rightarrow$ im1 зменшення суттєве (IVD = -1,405) і має наслідком перехід субценопопуляцій із категорії процвітаючих до врівноважених. У двох інших фітоценозах зменшення незначне (IVD становить $-0,536$ та -0,691). В угрупованні Quercetum (roboris) coryloso (avellanae)-convallariosum (majalis) воно відбувається в межах одного якісного типу врівноважених, а в Quercetum (roboris) acereto (tatarici)-urticosum (dioicae) супроводжується переходом із категорії врівноважених до депресивних. На етапі im1 $\rightarrow$ im2 збільшення індексу якості незначне (IVD варіює в межах від 0,187 до 0,803). У фітоценозі Quercetum (roboris) convallariosum (majalis) це зумовлює набуття онтогенетичною субценопопуляцією статусу процвітаючої. В угрупованнях Quercetum (roboris) coryloso (avellanae)convallariosum (majalis) тa Quercetum (roboris) acereto (tatarici)-urticosum (dioicae) субценопопуляції не змінюють свого якісного статусу.

Значення індексу віталітетної динаміки (IVD) та зміна якісного типу

Таблиця 2

\section{в онтогенетичних субценопопуляцій Quercus robur у досліджуваних угрупованнях}

\begin{tabular}{|c|c|c|c|}
\hline \multirow{2}{*}{ № } & \multirow{2}{*}{ Угруповання } & \multicolumn{2}{|c|}{ Перехід за етапами природного відновлення } \\
\hline & & $\mathrm{J} \rightarrow \mathrm{im} 1$ & $\mathrm{im} 1 \rightarrow \mathrm{im} 2$ \\
\hline \multirow{2}{*}{1} & \multirow{2}{*}{ Quercetum (roboris) convallariosum (majalis) } & $-1,405$ & 0,803 \\
\hline & & $\Pi \rightarrow \mathrm{B}$ & $\mathrm{B} \rightarrow \Pi$ \\
\hline \multirow{2}{*}{2} & \multirow{2}{*}{ Quercetum (roboris)-Acereto (platanoiditis) aegopodiosum (podagrariae) } & 0,058 & $-0,327$ \\
\hline & & $\Pi-\Pi$ & $\Pi \rightarrow \mathrm{B}$ \\
\hline \multirow{2}{*}{3} & \multirow{2}{*}{ Tilieto (cordatae)-Quercetum (roboris) coryloso (avellanae)-aegopodiosum (podagrariae) } & 0,015 & $-0,684$ \\
\hline & & $\Pi-\Pi$ & $\Pi \rightarrow \mathrm{B}$ \\
\hline \multirow{2}{*}{4} & \multirow{2}{*}{ Quercetum (roboris) coryloso (avellanae)-dryopteridosum (filix-maris) } & 0,335 & $-0,472$ \\
\hline & & $\mathrm{B} \rightarrow \Pi$ & $\Pi \rightarrow \mathrm{B}$ \\
\hline \multirow{2}{*}{5} & \multirow{2}{*}{ Quercetum (roboris) coryloso (avellanae)-convallariosum (majalis) } & $-0,536$ & 0,675 \\
\hline & & $\mathrm{B}-\mathrm{B}$ & $\mathrm{B}-\mathrm{B}$ \\
\hline \multirow{2}{*}{6} & \multirow{2}{*}{ Tilieto (cordatae)-Acereto (platanoiditis)-Quercetum (roboris) stellariosum (holosteae) } & $-0,238$ & $-0,837$ \\
\hline & & $\mathrm{B}-\mathrm{B}$ & $\mathrm{B} \rightarrow$ Д \\
\hline \multirow{2}{*}{7} & \multirow{2}{*}{ Quercetum (roboris) Acereto (tatarici)-urticosum (dioicae) } & $-0,691$ & 0,187 \\
\hline & & $\mathrm{B} \rightarrow$ Д & Д-Д \\
\hline
\end{tabular}

Примітки: у таблиці в першому рядку наведено значення індексу віталітетної динаміки (IVD), у другому - дані про зміну якісного типу когорти; літерами позначено: Д - депресивна когорта, В - врівноважена, П - процвітаюча.

Загалом, у Кролевецько-Глухівському геоботанічному районі у молодого покоління $Q$. robur на етапах онтогенетичного розвитку негативні зміни віталітетної структури проявляються частіше, ніж позитивні. При цьому значення індексу IVD в основному варіюють від $-0,837$ до 0,238. Зменшення життєвості особин та погіршення віталітетної структури здебільшого супроводжуються переходом онтогенетичних субценопопуляцій 3 одного якісного типу в інший (із процвітаючих до врівноважених або з урівноважених до депресивних).

\section{Висновки}

Онтогенетичні субценопопуляції молодого покоління Q. robur, які формуються під наметом широколистяних лісів Кролевецько-Глухівського геоботанічного району, вирізняються високим рівнем різноманіття віталітетної структури та належністю до всіх трьох виділених Ю.А. Злобіним якісних типів: процвітаючих, врівноважених і депресивних. Від наймолодших (j) до старших онтогенетичних субценопопуляцій (im2) має місце досить чітко виражена тенденція до збільшення представленості субценопопуляцій категорії «депресивні».

Перехід до кожного наступного етапу розвитку (від j до im1, а також від im1 до im2) супроводжується проявом у молодого покоління $Q$. robur віталітетної пластичності (тобто зміни індексу якості Q) та, відповідно, віталітетної мінливості (зміни частки особин різних класів віталітету). Динаміка значень індексу Q в онтогенетичних субценопопуляцій $Q$. robur у досліджуваних угрупованнях відповідає трьом варіантам змін. Їх аналіз доповнено визначенням оригінального індексу IVD: негативні зміни віталітетної структури проявляються частіше, ніж позитивні. У разі погіршення віталітетної структури здебільшого відбувається зниження якісного статусу когорт.

Віталітетна структура онтогенетичних субценопопуляцій ювенільних та імматурних (im1 та im2) рослин об'єктивно свідчить про ускладнення формування у фітоценозах за участі $Q$. robur безперервного потоку поколінь цього виду, та, відповідно, забезпечення стійкого та тривалого існування його ценопопуляцій. Виходячи 3 особливостей віталітетної структури та іiі динаміки, вважаємо, що у майбутньому у досліджу- 
ваному регіоні суттєва трансформація видового складу деревостанів внаслідок зменшення представленості у їх складі $Q$. robur можлива в угрупованнях Tilieto (cordatae)-Acereto (platanoiditis)-Quercetum (roboris) stellariosum (holosteae) та Quercetum (roboris) acereto (tatarici)-urticosum (dioicae).

\section{Бібліографічні посилання}

Andrijenko, T.L. (ed.), 2001. Zapovidni skarby Sumshhyny [Reserved treasures of Sumy region]. Dzherelo, Sumy (in Ukrainian).

Andrijenko, T.L., Bilyk, G.I., Bradis, J.M., Golubec, M.A., Mahajeva, L.V., Rubalov, M.I., Tkachenko, V.S., SheljagSosonko, J.R., 1977. Geobotanichne rajonuvannja Ukrai'ns'koi' RSR [Geobotanical division into districts of Ukrainian SSR]. Naukova dumka, Kyiv (in Ukrainian).

Bashtovoj, N.G., 1992. Cenopopuljacii travjanistyh rastenij shirokolistvennyh lesov v uslovijah rekreacionnyh nagruzok [Cenopopulations herbaceous plants deciduous forests in the conditions recreational loads]. Sumy (in Ukrainian).

Bobyliov, Y.P., Brygadyrenko, V.V., Bulakhov, V.L., Gaichenko, V.A., Gasso, V.Y., Didukh, Y.P., Ivashov, A.V., Kucheriavyi, V.P., Maliovanyi, M.S., Mytsyk, L.P., Pakhomov, O.Y., Tsaryk, I.V., Shabanov, D.A., 2014. Ekologija [Ecology]. Folio, Kharkiv (in Ukrainian).

Brewer, S., Cheddadi, R., L.Beaulien, J., Reilly, M., 2002. The spread of deciduous Quercus throughout Europe since the last glacial period. Forest Ecol. Manag. 156, 27-48.

Bukshtynov, A.D., 1959. Lesnye resursy SSSR i mira [Forest resources of the USSR and the world]. Izd-vo Ministerstva Sel'skogo Hozjajstva SSSR, Moscow (in Russian).

Burslem, D.F.R.P., Whitmore, T.C., 1999. Species diversity, susceptibility to disturbance and tree population dynamics in tropical rainforest. J. Veg. Sci. 10, 767-776.

Chistjakova, A.A., 1987. Polivariantnost' ontogeneza i tipy povedenija derev'ev shirokolistvennyh lesov [Polyalternativeness ontogeny and types of behavior trees of deciduous forests]. Populjacionnaja Jekologija Rastenij. Nauka, Moscow. 39-43 (in Russian).

Cramer, W., Whittaker, R., 1999. Changing the surface of our planet - results from studies of the global ecosystem. Global Ecol. Biogeogr. 8(5), 363-365.

Filipovitch, L., Lazarova, M., 2001. Composition and trends in the development of vegetation in the Western Rhodopes (Southwest Bulgaria) during the late-Glacial and Holocene. Phytol. Balcan. 7(2), 167-180.

Hunt, R., 1982. Plant growth curves: The functional approach to plant growth analysis. Edward Arnold, London.

Joshi, N.V., Suresh, H.S., Dattaraja, H.S., Sukumar, R., 1997. The spatial organization of plant communities in a deciduous forest: A computational - geometry - based analysis. J. Indian Inst. Sci. 77, 365-374.

Kashin, A.S., Zhulidova, T.V. (ed.)., 2009. Sostjanie cenopopuljacij Antennaria dioica (L.) Gaerth. v Saratovskoj oblasti [State of Antennaria dioica (L.) Gaerth. cenopopulations in the Saratov region]. Povolzhskij Jekologicheskij Zhurnal 3, 195-209 (in Russian).

Kaus, A., Schmitt, V., Simon, A., Wild, A., 1995. Microscopical and mycological investigations on wood of pedunculate oak (Quercus robur L.) relative to the occurrence of oak decline. J. Plant Physiol. 148, 302-308.

Kovalenko, I.M., 2006. Struktura populjacij dominantiv trav'jano-chagarnychkovogo jarusu $\mathrm{v}$ lisovyh fitocenozah Desnjans'ko-Staroguts'kogo nacional'nogo pryrodnogo parku. Vitalitetna struktura [The structure of the dominant populations of herb-layer in forest phytocenosis of Desnian-
sko-Starogutsky National Park. Vitality structure]. Ukr. Botan. Zhurn. 63(3), 376-386 (in Ukrainian).

Niinemets, U., 1998. Growth of young trees of Acer platanoides and Quercus robur along a gap-understory continuum: Interrelationships between allometry, biomass partitioning, nitrogen, and shade tolerances. Int. J. Plant Sci. 159(2), 318-330.

Oleksyn, J., Przybył, K., 1987. Oak decline in the Soviet Unionscale and hypotheses. Eur. J. Forest Pathol. 17, 321-336.

Panchenko, S.M., 2005. Vikova ta vitalitetna struktura populjacij Diphasiastrum complanatum s.l. u NPP «Desnjans'ko-Staroguts'kyj» [Age and vitality structure of Diphasiastrum complanatum s.l. populations in the NNP "Desniansko-Starogutsky"]. Ukr. Botan. Zhurn. 62 (5), 698-706 (in Ukrainian).

Panchenko, S.M., 2007. Populjacija Goodyera repens (L.) R. Br u Nacional'nomu Parku «Desnjans'ko-Staroguts'kyj» [Populations of Goodyera repens (L.) R. Br in National Park "Desniansko-Starogutsky"]. Ukr. Botan. Zhurn. 64(4), 526533 (in Ukrainian).

Panchenko, S.M., 2009. Cenopopuljacii' Chelidonium majus L. $\mathrm{v}$ lisah Novgorod-Sivers'kogo Polissja [Cenopopulations of Chelidonium majus L. in forests of the Novgorod-Seversky Polesye]. Ukr. Botan. Zhurn. 66(4), 518-528 (in Ukrainian).

Petit, R.J., Brewer, S., Borda'cs, S., Burg, K., Cheddadi, R., Coart, E., Cottrell, J., Csaikl, U.M., van Dam, B., Deans, J.D., Espinel, S., Fineschi, S., Finkeldey, R., Glaz, I., Goicoechea, P.G., Jensen, J.S., Konig, A.O., Lowe, A.J., Madsen, S.F., Matyas, G., Munro, R.C., Popescu, F., Slade, D., Tabbener, H., de Vries, S.G.M., Ziegenhagen, B., de Beaulieu, J.-L., Kremer A. 2002. Identification of refugia and post-glacial colonisation routes of European white oaks based on chloroplast DNA and fossil pollen evidence. Forest Ecol. Manag. 156(1), 49-74.

Popadyuk, R., Smirnova, O., Evstigneev, O., Yanitskaya, T., Chumatchenko, S., Zaugolnova, L., Korotkov, V., Chistyakova, A., Khanina, L., Komarov, A., 1995. Current state of broad-leaved forests in Russia, Belorussia, Ukraine: Historical development, biodiversity, structure and dynamic. PRC RAS, Pushchino.

Rysin, L.P., 1990. Dub obyknovennyj [Pedunculate oak]. Biologicheskaja flora Moskovskoj oblasti, Izd-vo MGU, Moscow. 102-131 (in Russian).

Schütz, J.-P., 2002. Polyvalentner Waldbau. Skript zur Vorlesung Waldbau IV. Professur Waldbau, ETH-Zentrum. Zürich.

Sheljag-Sosonko, J.R., 2001. Lisy Ukrai'ny: Bioriznomanitnist' ta zberezhennja [Forests of Ukraine: Biodiversity and preservation]. Ukr. Botan. Zhurn. 58(5), 519-529 (in Ukrainian).

Sheljag-Sosonko, J.R., 2003. Ekologichne ta social'ne znachennja lisiv [Environmental and social significance of forests]. Menedzhment Ohoronnyh Lisiv Ukrai'ny. Fytosocyocentr, Kyiv. 10-23 (in Ukrainian).

Skljar, V.G., 2013. Dynamika vitalitetnyh parametriv lisoutvorjuval'nyh vydiv Novgorod-Sivers'kogo Polissja: Teoretychni zasady ta sposoby ocinky [Dynamics vitality parameters forest-forming species of the Novgorod-Seversky Polesye: Theoretical principles and methods of evaluation]. Ukr. Botan. Zhurn. 70(5), 624-630 (in Ukrainian).

Skljar, V.G., 2015. Pryrodne vidnovlennja jak mehanizm zabezpechennja funkcionuvannja lisovyh fitocenoziv Livoberezhnogo Polissja Ukrai'ny (populjacijni ta ekologo-cenotychni aspekty) [Natural regrowth as a mechanism for ensuring of functioning of forest phytocenosis on Left bank Ukraine Polissya (population and eco-coenotic aspects)]. In-t Botaniky im. M.G. Holodnogo, Kyiv (in Ukrainian).

Smirnova, O.V., Chistyakova, A.A., Zaugolnova, L.B., 1999. Ontogeny of a tree. Botan. Zh. 84(12), 8-20.

Stojko, S.M., 2006. Pralisy jak ekologichni modeli dlja renaturalizacii' vtorynnyh fitocenoziv [Virgin forests as ecological 
model for renaturalization secondary plant phytocenoses]. Ukr. Botan. Zhurn. 3, 358-368 (in Ukrainian).

Suhoj, I.B., 1986. Differenciacija cenopopuljacij rastenij v shirokolistvennyh lesah Srednerusskoj vozvyshennosti (Ukrainskaja SSR) [Differentiation cenopopulations of plants in deciduous forests the Central Russian Upland (Ukrainian SSR)]. Sumy (in Ukrainian).

Sytnyk, K.M., 2003. Zberezhennja ta vidtvorennja lisovyh bagatstv Ukrai'ny [The preservation and reproduction of forest resources Ukraine]. Ukr. Botan. Zhurn. 60(1), 3-5 (in Ukrainian).

Thomas, F.M., 2008. Recent advances in cause-effect research on oak decline in Europe. CAB Rev.: Perspect. Agric. Vet. Sci. Nutr. Nat. Resour. 37(3), 1-12.
Thomas, W.D., Boza, C.A., 1984. The oak decline complex. J. Arbor. 10, 170-177.

Zlobin, J.A., 1989. Principy i metody izuchenija cenoticheskih populjacij rastenij [Principles and methods for the study of plant cenopopulations]. Kazan' Univ. Press, Kazan' (in Russian).

Zlobin, J.A., 1989. Teorija i praktika ocenki vitalitetnogo sostava cenopopuljacij rastenij [Theory and practice of evaluation vitality structure cenopopulations of plants]. Botan. Zh. 74(6), 769-781 (in Russian).

Zlobin, J.A., 2009. Populjacionnaja jekologija rastenij: Sovremennoe sostojanie, tochki rosta [Population ecology of plants: Modern state, points of growth]. Universitetskaja Kniga, Sumy (in Ukrainian).

Надійшла до редколегї 10.07.2015 